\title{
Cold exposure down-regulates adiponutrin/PNPLA3 mRNA expression and affects its nutritional regulation in adipose tissues of lean and obese Zucker rats
}

\author{
Paula Oliver ${ }^{1}$, Antoni Caimari ${ }^{1,2}$, Rubén Díaz-Rúa ${ }^{1}$ and Andreu Palou ${ }^{1 *}$ \\ ${ }^{1}$ Laboratory of Molecular Biology, Nutrition and Biotechnology, Universitat de les Illes Balears and CIBER de Fisiopatología \\ de la Obesidad y Nutrición (CIBERobn), Carretera Valldemossa Km 7.5, E-07122 Palma de Mallorca, Spain \\ ${ }^{2}$ Technological Center of Nutrition and Health (CTNS), Reus, Spain \\ (Submitted 4 March 2011 - Final revision received 1 July 2011 - Accepted 10 July 2011 - First published online 14 September 2011)
}

\section{Abstract}

Adiponutrin/PNPLA3 is a protein highly produced in adipose tissue whose expression is under tight nutritional regulation. It possesses lipogenic/lipolytic capacity and, although adiponutrin polymorphisms are related to obesity, its physiological role is not clear. To help clarify its role, we studied the effect of acute cold exposure on adiponutrin mRNA expression in different adipose tissues of lean/obese Zucker rats subjected to feeding/fasting/refeeding. The effect of cold on the expression of key lipogenic enzymes and on uncoupling protein-1 (UCP1) was evaluated in selected adipose depots. Adiponutrin mRNA levels were also determined in the adipose tissue of isoprenaline-treated rats and in cultured adipocytes treated with noradrenaline, isoprenaline and a selective $\beta 3$-adrenoceptor (AR) agonist. Adiponutrin expression was strongly down-regulated by cold in the different adipose depots in lean animals, while this down-regulation was impaired in obese rats. Adiponutrin pattern of expression in response to cold correlated positively with that of the lipogenic enzymes and negatively with UCP1 expression. Acute intraperitoneal administration of isoprenaline also produced a decrease in adiponutrin expression in adipose tissue. In vitro data suggest that adiponutrin's inhibitory effect could be mediated, at least in part, by the sympathetic system via $\beta 1 / \beta 2$-AR. In addition, improvement in metabolic parameters related to obesity in cold-exposed animals was related to an improvement in adiponutrin nutritional regulation. Thus, cold inhibition of adiponutrin expression in adipose tissue (which correlates with the response of lipogenic enzymes) supports a physiological role for this protein in lipogenesis. Moreover, alterations in adiponutrin expression and regulation in adipose tissue are related to obesity.

Key words: Adiponutrin: PNPLA3: Obesity: Cold exposure

Adiponutrin, also known as PNPLA3, is a non-secreted transmembrane protein that is highly expressed in the adipose tissue, and whose expression levels increase during adipocyte differentiation $^{(1,2)}$. This protein belongs to the phospholipase A2 family and the human isoform, iPLA2 $\varepsilon$, has been described to possess both lipase and transacylase activity in vitro, the latter defining a previously unknown pathway of TAG synthesis in adipocytes ${ }^{(2)}$. Hence, adiponutrin could participate in lipid homeostasis by facilitating both lipolysis and lipogenesis ${ }^{(2)}$. However, in vitro suppression or overexpression of adiponutrin, as well as its deletion in vivo, does not affect TAG hydrolysis ${ }^{(3-5)}$, which goes against a lipolytic role for this protein.

Adiponutrin gene expression is highly regulated by feeding conditions: mRNA levels dramatically decrease after fasting (and recover by refeeding) in rodents ${ }^{(1,6-8)}$, and decrease as a result of short- or long-term energy restriction in humans ${ }^{(9)}$ Nutritional regulation of adiponutrin seems to be mediated by insulin and glucose. Both signals increase mRNA expression in vivo and in vitro ${ }^{(1,4,10)}$, and its expression is decreased in models of altered insulin action ${ }^{(4)}$ and increased in human subjects by hyperinsulinaemia ${ }^{(11)}$. Although the exact biological function of adiponutrin in adipose tissue remains yet unclear, all these facts point towards a role in promoting adipocyte energy storage and glucose homeostasis in situations of energy excess, with this protein playing a lipogenic rather than a lipolytic function in adipocytes ${ }^{(2,10,12)}$. Further evidence supporting a role of adiponutrin in lipogenesis comes from recent studies demonstrating that the lipogenic transcription factor sterol regulatory element binding protein 1c promotes adiponutrin mRNA expression in hepatocytes $^{(13,14)}$, and this is similar to what happens with genes

Abbreviations: ACC1, acetyl-CoA carboxylase-1; AR, adrenoceptor; FAS, fatty acid synthase; HOMA-IR, homeostatic model assessment for insulin resistance; LRP10, lipoprotein receptor-related protein 10; MEF, mouse embryonic fibroblasts; SCD1, stearoyl-CoA desaturase-1; UCP-1, uncoupling protein-1. 
involved in lipogenesis ${ }^{(15)}$. However, other studies have suggested that adiponutrin function could have a different role in liver. Data relating an adiponutrin polymorphism to an increased risk of hepatic steatosis in human subjects seem to indicate an important role of this protein in lipid metabolism regulation $^{(16,17)}$, and, recently, it has been demonstrated in cultured hepatocytes that human wild-type adiponutrin hydrolyses TAG, while a mutation disrupts this function, leading to fat accumulation ${ }^{(18)}$. Nevertheless, in mice, loss of adiponutrin has no effect on body weight or composition, mass or development of adipose tissue, and does not cause fatty liver ${ }^{(5,19)}$.

Adiponutrin expression appears to be related to obesity, as it has been described that it is overexpressed in subcutaneous white adipose tissue and in brown adipose tissue of obese rats ${ }^{(1,20)}$. In human subjects, although the results are contradictory (probably due to the degree of insulin resistance) ${ }^{(11)}$, an increase in adiponutrin expression in subcutaneous and visceral adipose tissue has also been reported ${ }^{(10)}$. Moreover, two human adiponutrin polymorphisms have been shown to be associated with obesity and type 2 diabetes, as well as with insulin secretion ${ }^{(10,21)}$. In addition, our group has described that adiponutrin nutritional regulation is impaired in obese rats ${ }^{(20)}$.

Cold is a situation that produces extensive mechanisms of adaptation in adipose tissue affecting the process of lipolysis and adipokine production ${ }^{(22)}$. Different adipokines, such as leptin, have been shown to be affected by cold to a greater or lesser extent ${ }^{(23)}$. In obesity, the sympathetic sensitivity of adipose tissue and, thus, cold response, is reduced, and this factor may underlie dysregulation of leptin production and other adipose tissue secretions, and contribute to the development of obesity ${ }^{(24)}$. Although it is not secreted and cannot be exactly defined as an adipokine, adiponutrin shares many of the characteristic features of adipose-specific adipokines, especially leptin, which has an important role in energy homeostasis $^{(25)}$. Actually, due to their similarity, adiponutrin has been related to the same regulatory pathway as leptin, although the exact relationship between these two proteins has not yet been established. It is known that leptin expression is strongly down-regulated by cold $^{(26)}$ but up to date, no data exist regarding adiponutrin regulation in response to a cold stimulus.

In the present study, we have analysed the effect of $24 \mathrm{~h}$ cold exposure on adiponutrin mRNA expression in different adipose tissue depots of lean and obese Zucker rats and its relationship with cold regulation of the adipokine leptin and of important lipogenic enzymes. Moreover, we have analysed the effect of cold exposure on adiponutrin expression in rats subjected to different feeding conditions (fasting/refeeding). We have also analysed adiponutrin expression in Wistar rats with intraperitoneal administration of isoprenaline and the in vitro effect of noradrenaline, isoprenaline and a specific $\beta 3$-agonist treatment in cultures of white and brown adipocytes. In addition, due to its importance in mediating the cold response, we have analysed mRNA expression of the $\beta 3$-adrenergic receptor, both in vivo and in vitro. The understanding of the regulation of adiponutrin gene expression in response to a cold stimulus could contribute to clarify the role of this protein in lipid metabolism, which is strongly affected in a cold situation.

\section{Experimental methods}

\section{Animals}

Male Zucker rats, 3 months old, both lean (fa/?) and obese (fa/fa; Charles River Laboratories España SA, Barcelona, Spain) fed with a standard chow diet (Panlab, Barcelona, Spain) were used. They were housed at $22^{\circ} \mathrm{C}$ with a period of $12 \mathrm{~h}$ light $-12 \mathrm{~h}$ dark (lights on at 08.00 hours) and with free access to food and water. The gross composition of the diet was as follows: $60.5 \%$ carbohydrate, $2.9 \%$ lipid, $15.4 \%$ protein, $12 \%$ water, $3.9 \%$ fibre and $5.3 \%$ minerals. Rats were distributed into two experimental groups: control group ( $n$ 5), with animals acclimatised to $22^{\circ} \mathrm{C}$, and cold group ( $n$ 15), with animals housed at $4^{\circ} \mathrm{C}$ for $24 \mathrm{~h}$. Animals of the cold group were divided into three different feeding conditions (five animals for each condition): a control-fed group, animals provided with ad libitum access to a chow diet; a fasted group, animals deprived of food for $14 \mathrm{~h}$ (nocturnal fasting); a refed group, fasted animals with later free access to a chow diet for $3 \mathrm{~h}$. In the fed animals, food intake was recorded during the $24 \mathrm{~h}$ of the experimental period. Animals were weighed before and after exposure to each temperature.

Animals of the fed and fasted groups were killed by decapitation at the beginning of the light cycle (09.00-11.00 hours), and animals of the refed group (with access to food for $3 \mathrm{~h}$ after a nocturnal fasting) were killed from 11.00 to 12.00 hours. Different white adipose tissue depots, both internal (epididymal, mesenteric and retroperitoneal) and subcutaneous (inguinal), as well as the interscapular brown adipose tissue were rapidly removed after death, weighed, frozen in liquid $\mathrm{N}_{2}$ and stored at $-70^{\circ} \mathrm{C}$ until RNA analysis. Blood was also collected, stored at room temperature for $1 \mathrm{~h}$ and then centrifuged at $1000 \mathrm{~g}$ for $10 \mathrm{~min}$ to obtain the serum.

Additionally, 3-month-old male Wistar rats fed with a standard chow diet and housed at $22^{\circ} \mathrm{C}$ were used to study the effect of an acute treatment with the non-specific $\beta$-agonist isoprenaline (Sigma, Madrid, Spain). Animals were divided into two groups: control group ( $n 5$ ) and isoprenaline-treated group ( $n$ 5). Animals were treated with two intraperitoneal injections of isoprenaline $(5 \mathrm{mg} / \mathrm{kg}$ body weight dissolved in saline) separated by $6 \mathrm{~h}$ (first injection was at 09.00 hours). Control animals received vehicle only. At $2 \mathrm{~h}$ after the last injection, animals were killed. The different adipose tissue depots and blood were collected in the same conditions described above. Rats had free access to food and food intake was recorded during the experiment.

The animal protocol followed in the present study was reviewed and approved by the Bioethical Committee of our university and the guidelines for the use and care of laboratory animals of the university were followed.

\section{Adiposity index}

Adiposity was determined by an adiposity index computed for each rat as the sum of epididymal, inguinal, mesenteric and 
retroperitoneal white adipose tissue depot weights, and is expressed as a percentage of total body weight.

\section{Quantification of circulating insulin, leptin, NEFA and glucose levels}

Serum insulin and leptin levels were measured using ELISA kits (DRG Instruments, Marburg, Germany and R\&D Systems, Minneapolis, MN, USA, respectively) and NEFA levels using an enzymatic colorimetric NEFA C kit (WAKO, Neuss, Germany). Blood glucose was measured using an Accu-Chek Glucometer (Roche Diagnostics, Barcelona, Spain).

\section{Homeostatic model assessment for insulin resistance analysis}

Insulin resistance was assessed by the homeostatic model assessment for insulin resistance (HOMA-IR) in rats subjected to overnight ( $14 \mathrm{~h}$ ) fasting ( $n 5$, for all groups). The HOMA-IR score was calculated from fasting insulin and glucose concentrations using the formula of Matthews et $a l^{(27)}$ :

$$
\begin{aligned}
\text { HOMA-IR }= & \text { fasting glucose }(\mathrm{mmol} / \mathrm{l}) \\
& \times \text { fasting insulin }(\mathrm{mU} / \mathrm{l}) / 22 \cdot 5 .
\end{aligned}
$$

\section{Cell culture}

Brown adipose tissue precursor cells from cervical, axillary and interscapular brown fat depots of 4-week-old male NMRI mice (CRIFFA, Barcelona, Spain) were prepared, inoculated and cultured as described earlier ${ }^{(28)}$, in six-well multidish plates, at $37^{\circ} \mathrm{C}$ and in an atmosphere of $8 \% \mathrm{CO}_{2}$ in air. The culture medium consisted of Dulbecco's modified Eagle's medium supplemented with $10 \%$ newborn calf serum, $4 \mathrm{~nm}$-insulin, $10 \mathrm{~mm}$-HEPES, $2 \mathrm{~mm}$-glutamine, penicillin $(30 \mu \mathrm{g} / \mathrm{ml})$, streptomycin $(50 \mu \mathrm{g} / \mathrm{ml})$ and sodium ascorbate $(25 \mu \mathrm{g} / \mathrm{ml})$, which was changed on the $1 \mathrm{st}$, 3rd and 6 th day after inoculation. The cells were treated with a single dose of noradrenaline (from $10^{-8}$ to $10^{-5} \mathrm{M}$ ) or vehicle (water) on day 6 , together with fresh medium and harvested $24 \mathrm{~h}$ later.

As a model of white adipose cells, primary mouse embryonic fibroblasts (MEF) were used. MEF were prepared and cultured essentially as described previously ${ }^{(29)}$, in twelvewell multidish plates, at $37^{\circ} \mathrm{C}$ and in an atmosphere of $5 \%$ $\mathrm{CO}_{2}$ in air. MEF on passage 3-4 were grown to confluence in AmnioMAX ${ }^{\mathrm{TM}}-\mathrm{C} 100$ basal medium supplemented with 7.5\% AmnioMAX ${ }^{\mathrm{TM}}-\mathrm{C} 100$ supplement, $7 \cdot 5 \%$ fetal bovine serum, penicillin $(30 \mu \mathrm{g} / \mathrm{ml})$, streptomycin $(50 \mu \mathrm{g} / \mathrm{ml})$ and $2 \mathrm{~mm}$-L-glutamine. For differentiation into white adipocytes, $2 \mathrm{~d}$ post-confluent cells (day 0) were treated with growth medium containing $1 \mu \mathrm{m}$-dexamethasone, $0.5 \mathrm{~mm}$-isobutylmethylxanthine, insulin $(5 \mu \mathrm{g} / \mathrm{ml})$ and $0.5 \mu \mathrm{m}$-rosiglitazone for $48 \mathrm{~h}$; the cells were subsequently refed every other day with fresh medium containing insulin $(5 \mu \mathrm{g} / \mathrm{ml})$ and $0.5 \mu \mathrm{M}-$ rosiglitazone. From day 6 , cells were deprived of insulin and rosiglitazone. The cells were treated with noradrenaline (from $10^{-8}$ to $10^{-5} \mathrm{M}$ ) or vehicle (water) on day 8 , together with fresh medium and harvested $24 \mathrm{~h}$ later. Parallel cultures of white adipocytes were also treated with isoprenaline (from $10^{-7}$ to $10^{-5} \mathrm{M}$ ) and with CL 316243 , a selective $\beta 3$ adrenoceptor (AR) agonist, in the same doses and conditions as those described for noradrenaline.

Noradrenaline, isoprenaline and CL 316243 were obtained from Sigma. Sera were from Linus (Cultek, Madrid, Spain), Dulbecco's modified Eagle's medium from Sigma, and AmnioMAX $^{\mathrm{TM}}$-C100 basal medium and AmnioMAX ${ }^{\mathrm{TM}}-\mathrm{C} 100$ supplement were from Gibco (Invitrogen, Barcelona, Spain). Other cell culture reagents were supplied by Sigma.

Adipogenesis was monitored by morphological examination of lipid accumulation in the cells using phase-contrast microscopy. The treatment with noradrenaline, isorprenaline or CL 316243 was carried out by the time the cells had reached confluence and a high percentage of them had acquired the typical differentiated adipocyte morphology, i.e. they were rounded up and showed lipid accumulation in multivacuolar droplets. Uncoupling protein-1 (UCP1) mRNA expression was detected in brown adipocytes as a terminal marker of differentiation in order to test that the brown cells were properly differentiated. As expected ${ }^{(30)}$, there was a dose-dependent increase in UCP1 mRNA levels in primary cultured brown adipocytes treated with noradrenaline (data not shown).

For harvesting, the culture medium was removed, and the cells were rinsed with PBS $(137 \mathrm{~mm}-\mathrm{NaCl}, 2.7 \mathrm{~mm}-\mathrm{KCl}$ and $10 \mathrm{~mm}$-phosphate buffer, $\mathrm{pH}$ 7.4) and then scraped into $1 \mathrm{ml}$ Tripure with a rubber policeman, and transferred to an Eppendorf tube to continue the RNA extraction.

\section{RNA extraction}

Total RNA from the different white adipose tissue depots studied (epididymal, inguinal, mesenteric and retroperitoneal), from the interscapular brown adipose tissue as well as from cultured mouse brown adipocytes and white adipocytes differentiated from MEF, was extracted by Tripure Reagent (Roche Diagnostics GmbH, Mannheim, Germany), according to the manufacturer's instructions. The integrity and concentration of RNA were confirmed using agarose gel electrophoresis.

\section{Real-time quantitative PCR analysis}

Because good specific antibodies for rodent adiponutrin are not yet commercially available, we focused the present study on mRNA expression.

Briefly, $0.5 \mu \mathrm{g}$ of total RNA (in a final volume of $20 \mu \mathrm{l}$ ) were denatured at $90^{\circ} \mathrm{C}$ for $1 \mathrm{~min}$ and then reverse-transcribed to complementary DNA using murine leukemia virus RT (according to Applied Biosystems' procedure; Madrid, Spain) at $42^{\circ} \mathrm{C}$ for $1 \mathrm{~h}$, with a final step of $5 \mathrm{~min}$ at $99^{\circ} \mathrm{C}$ in a Perkin Elmer 9700 Thermal Cycler (Norwalk, CT, USA). Real-time PCR was completed using the LightCycler System with SYBR Green I sequence non-specific detection (Roche Diagnostics $\mathrm{GmbH}$ ). Primers for the different genes are described in Tables 1 and 2. All primers were obtained from Sigma Genosys (Sigma Aldrich Química SA, Madrid, Spain). 
Table 1. Nucleotide sequences of primers and cycling conditions used for PCR amplification in the adipose depots studied

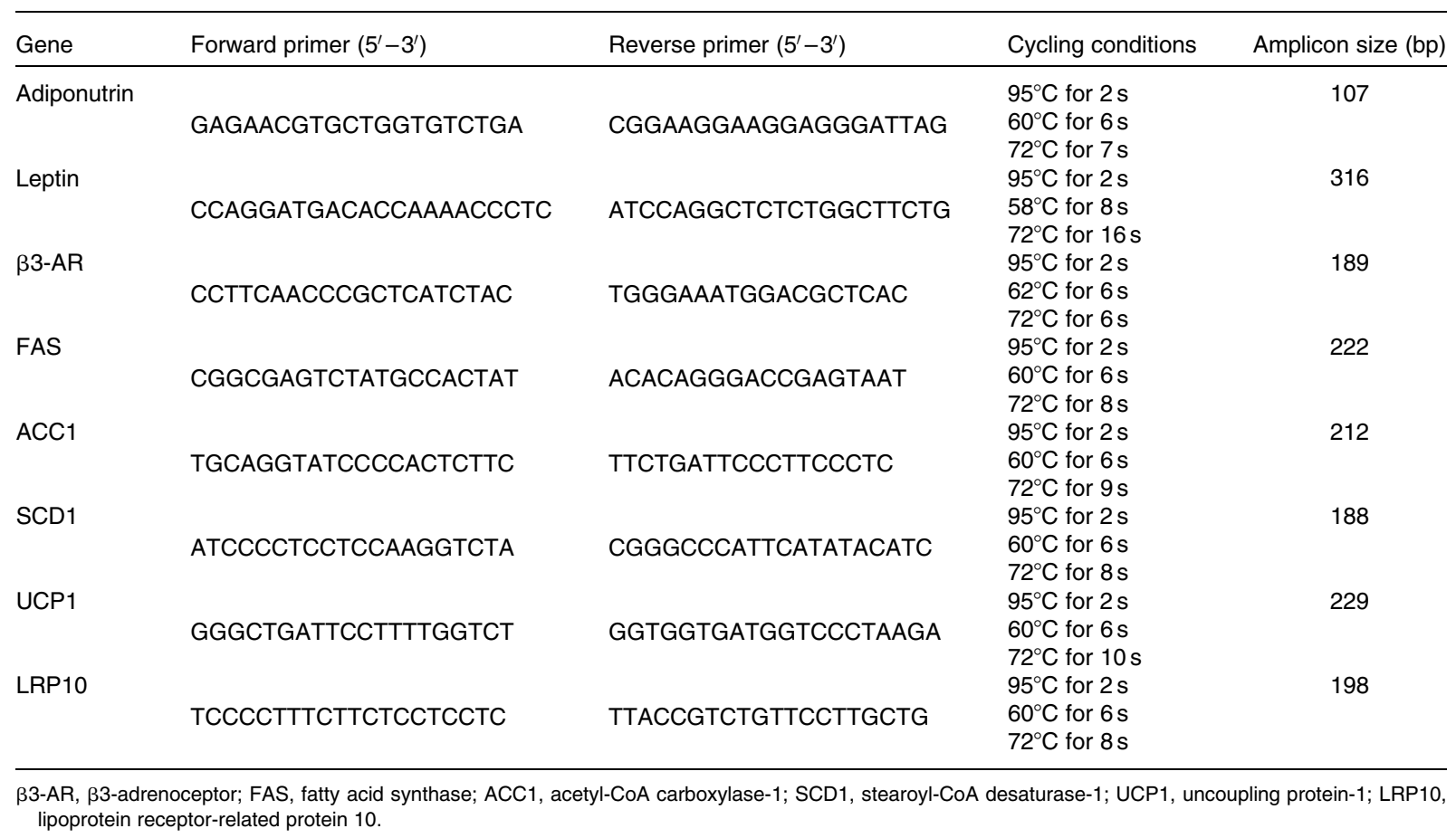

Each PCR was performed in a total volume of $10 \mu \mathrm{l}$, made from diluted (1:40) complementary DNA template $(2 \mu \mathrm{l})$, forward and reverse primers ( $1 \mu \mathrm{M}$ each), and SYBR Green I master mix $(1.8 \mu \mathrm{l}$, including Taq polymerase, reaction buffer, $\mathrm{MgCl}_{2}$, SYBR Green I dye and deoxyribonucleotide triphosphate mix). After an initial Taq activation at $95^{\circ} \mathrm{C}$ for $10 \mathrm{~min}$, LightCycler PCR was performed using forty to fortyfive cycles, with the cycling conditions described in Tables 1 and 2. In order to verify the purity of the products, a melting curve was produced after each run by increasing the temperature of the reaction mixtures up to $95^{\circ} \mathrm{C}$, by $0 \cdot 1^{\circ} \mathrm{C} / \mathrm{s}$, starting at $55^{\circ} \mathrm{C}$ for $10 \mathrm{~s}$. Values for the threshold $\left(C_{\mathrm{t}}\right)$ were determined using LightCycler software (Roche Diagnostics $\mathrm{GmbH}$ ).

Relative gene expression numbers were calculated as a percentage of control rats, using the $2^{-\Delta \Delta \mathrm{C} t} \operatorname{method}^{(31)}$, with lipoprotein receptor-related protein 10 (LRP10) as a reference gene. We selected LRP10 as reference because it has been described as a good choice for expression studies in adipose tissue $^{(32)}$. In cultured cells treated with isoprenaline, the gene used as reference was guanosine diphospate dissociation inhibitor 1, which we have previously identified as a good constitutive gene based on microarray studies ${ }^{(33)}$.

\section{Statistical analysis}

All data are expressed as means with their standard errors. The statistical significance of differences in body weight, adipose depot weights, adiposity index, HOMA-IR score and circulating insulin and leptin levels between the control and cold groups for lean and obese rats was assessed by twoway ANOVA and least significant difference post hoc comparisons, and the effect of cold exposure or obesity by Student's $t$ test. Significance for the different mRNA studied between the control and cold groups in the distinct adipose tissue depots and for lean and obese rats was assessed by two-way and three-way ANOVA and least significant difference post boc

Table 2. Nucleotide sequences of primers and cycling conditions used for PCR amplification in brown and white adipose cells in culture

\begin{tabular}{|c|c|c|c|c|}
\hline Gene & Forward primer $\left(5^{\prime}-3^{\prime}\right)$ & Reverse primer $\left(5^{\prime}-3^{\prime}\right)$ & Cycling conditions & Amplicon size (bp) \\
\hline Adiponutrin & & & $95^{\circ} \mathrm{C}$ for $2 \mathrm{~s}$ & 107 \\
\hline & GAGAACGTGCTGGTGTCTGA & CGGAAGGAAGGAGGGATTAG & $\begin{array}{l}60^{\circ} \mathrm{C} \text { for } 6 \mathrm{~s} \\
72^{\circ} \mathrm{C} \text { for } 7 \mathrm{~s}\end{array}$ & \\
\hline$\beta 3-A R$ & & & $95^{\circ} \mathrm{C}$ for $2 \mathrm{~s}$ & 121 \\
\hline & CAGAGTCCACCGCTCAACA & GGGGCAACCAGTCAAGAAG & $\begin{array}{l}61^{\circ} \mathrm{C} \text { for } 6 \mathrm{~s} \\
72^{\circ} \mathrm{C} \text { for } 5 \mathrm{~s}\end{array}$ & \\
\hline LRP10 & АCTGCACCTGGGTTATCCTG & GGGAGATTGGTGGCTGTA & $\begin{array}{l}95^{\circ} \mathrm{C} \text { for } 2 \mathrm{~s} \\
60^{\circ} \mathrm{C} \text { for } 6 \mathrm{~s} \\
72^{\circ} \mathrm{C} \text { for } 7 \mathrm{~s}\end{array}$ & 122 \\
\hline Gdi & CCGCACAAGGCAAATACATC & GACTCTCTGAACCGTCATCAA & $\begin{array}{l}95^{\circ} \mathrm{C} \text { for } 2 \mathrm{~s} \\
60^{\circ} \mathrm{C} \text { for } 6 \mathrm{~s} \\
72^{\circ} \mathrm{C} \text { for } 7 \mathrm{~s}\end{array}$ & 210 \\
\hline
\end{tabular}

ß3-AR, $\beta 3$-adrenoceptor; LRP10, lipoprotein receptor-related protein 10; Gdi, guanosine diphospate dissociation inhibitor 1. 
comparisons. In cold-exposed animals, the statistical significance of the different mRNA studied between the adipose tissue depots for the different feeding conditions was also assessed by two-way ANOVA and least significant difference post hoc comparisons. The effect of obesity on the mRNA expression studied in the different adipose depots of the cold group was assessed by Student's $t$ test. The effect of isoprenaline treatment on adiponutrin expression in the adipose tissue of Wistar rats was assessed by Student's $t$ test. In adipocyte cultures, the effect of the treatment with different doses of noradrenaline was assessed by one-way ANOVA. Linear relationships between key variables were tested using Pearson's correlation coefficients. The analyses were performed with SPSS $^{\circledR}$ for Windows (SPSS, Chicago, IL, USA). Threshold of significance was defined at $P<0.05$ and is indicated when different.

\section{Results}

\section{Body weight, adiposity, food intake and circulating} parameters: effect of cold exposure

Obese Zucker rats presented a $22 \%$ higher body weight, a higher adiposity index, were hyperleptinaemic, hyperinsulinaemic and insulin resistant as indicated by a higher HOMAIR score, and had higher circulating NEFA levels (Table 3). Cold exposure produced a decrease in circulating leptin and NEFA levels in lean and obese Zucker rats and an important decrease in insulin levels of obese rats (3.3-fold decrease; Table 3). It is of note that as a result of cold exposure, there was a reduction in food intake of approximately 38\%, in both lean and obese rats (Student's $t$ test, $P<0.05$ ).

\section{Effect of cold exposure on adiponutrin, leptin and $\beta 3$-adrenergic receptor $m R N A$ levels in different adipose tissue depots}

Consistent with a previous report ${ }^{(20)}$, there were site-specific differences in adiponutrin mRNA expression in lean rats acclimatised to $22^{\circ} \mathrm{C}$ - with the lowest levels found in the inguinal white adipose depot - and this expression was affected by obesity (two-way ANOVA, $P<0 \cdot 05$; Fig. 1(a)). As described previously ${ }^{(1,20)}$, adiponutrin mRNA levels were increased in the brown adipose tissue and in the inguinal white adipose tissue of obese animals in comparison with their lean counterparts (Student's $t$ test, $P<0.05$ ).

In lean rats, $24 \mathrm{~h}$ of cold exposure produced a sharp decrease of adiponutrin expression in the interscapular brown adipose tissue (88\%) and in the different white depots studied - epididymal, mesenteric and retroperitoneal (52, 82 and $78 \%$, respectively) - (Student's $t$ test, $P<0.05$ ), with the probable exception of the inguinal adipose tissue, where the decrease (41\%) was not statistically significant. In obese rats, the inhibitory effect of cold exposure was much lower than in lean rats and the decrease attained statistical significance only in the brown adipose tissue (32\%) and in the retroperitoneal white adipose tissue (39\%) (Student's $t$ test, $P<0.05)$

Regarding leptin (Fig. 1(b)), at $22^{\circ} \mathrm{C}$, as described previously $^{(20,34)}$, there was a depot-specific expression pattern and, in obese rats, expression was increased in the brown adipose tissue and in the inguinal white adipose tissue, concordant with higher circulating leptin levels in these animals. The effect of cold exposure on leptin expression was different from that observed for adiponutrin. A decrease in leptin expression as a result of cold exposure was evident only in the brown adipose tissue of both lean and obese rats - 58 and $36 \%$ of decrease, respectively - (Student's $t$ test, $P<0.05)$. In lean rats, cold produced no effect on leptin expression in any of the white depots studied, with the exception of the inguinal depot where an increase was observed (Student's $t$ test, $P<0 \cdot 05$ ). In obese rats, cold exposure increased leptin expression in the different white depots studied, especially in the inguinal depot (one-way ANOVA, $P<0.05$ ), although this increase was not translated into a parallel increase in circulating leptin levels.

$\beta 3$-Adrenergic receptor is an important mediator of the physiological action of cold. As shown in Fig. 1(c), in obese

Table 3. Body weight, serum parameters (insulin, leptin and NEFA) and homeostatic model assessment for insulin resistance (HOMA-IR) in ad libitum-fed control and cold-exposed lean and obese Zucker rats (Mean values with their standard errors, $n 5$ )

\begin{tabular}{|c|c|c|c|c|c|c|c|c|}
\hline & \multicolumn{4}{|c|}{ Zucker lean } & \multicolumn{4}{|c|}{ Zucker obese } \\
\hline & \multicolumn{2}{|c|}{ Control } & \multicolumn{2}{|c|}{ Cold } & \multicolumn{2}{|c|}{ Control } & \multicolumn{2}{|c|}{ Cold } \\
\hline & Mean & SEM & Mean & SEM & Mean & SEM & Mean & SEM \\
\hline Body weight (g) & 328 & 9 & 321 & 10 & $404^{*}$ & 17 & 391 & 16 \\
\hline Adiposity index (\%)† & 2.52 & 0.22 & $2 \cdot 31$ & 0.13 & $8 \cdot 69^{*}$ & 0.13 & $8 \cdot 68$ & 0.22 \\
\hline Insulin $(\mu \mathrm{g} / \mathrm{l}) \ddagger$ & 0.79 & 0.11 & 0.68 & 0.21 & $19 \cdot 2^{\star}$ & 4.9 & $5 \cdot 81^{*}$ & 1.58 \\
\hline Leptin $(\mu \mathrm{g} / \mathrm{l}) \ddagger$ & 3.47 & 0.24 & $2.63 \S$ & 0.46 & $41 \cdot 1^{*}$ & 2.9 & $31 \cdot 7 \S$ & $2 \cdot 0$ \\
\hline NEFA (mM)‡ & 0.82 & 0.06 & $0.40 \S$ & 0.08 & $1 \cdot 36^{*}$ & 0.02 & $0.97 \S$ & $0 \cdot 10$ \\
\hline HOMA-IR\| & 1.83 & $0 \cdot 21$ & $1 \cdot 21$ & 0.30 & $21 \cdot 2^{*}$ & $3 \cdot 3$ & $16 \cdot 4$ & $2 \cdot 8$ \\
\hline
\end{tabular}

* Mean values were significantly different for the effect of obesity $(P<0.05$; Student's $t$ test).

$\dagger$ The adiposity index was computed as the sum of epididymal, inguinal, mesenteric and retroperitoneal white adipose tissue depot weights, and is expressed as a percentage of total body weight.

‡ Insulin and leptin levels were measured by ELISA and NEFA levels using an enzymatic colorimetric kit.

$\S$ Mean values were significantly different for the effect of cold exposure $(P<0.05$; Student's $t$ test $)$.

II HOMA-IR was computed using the formula of Matthews et al. ${ }^{(27)}$. 


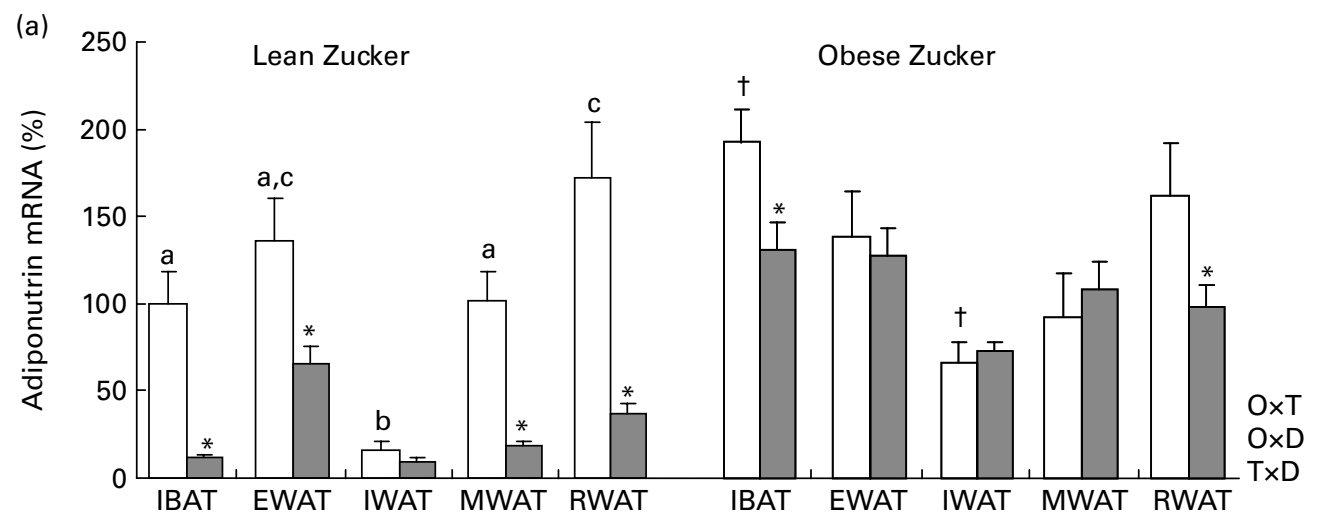

(b)
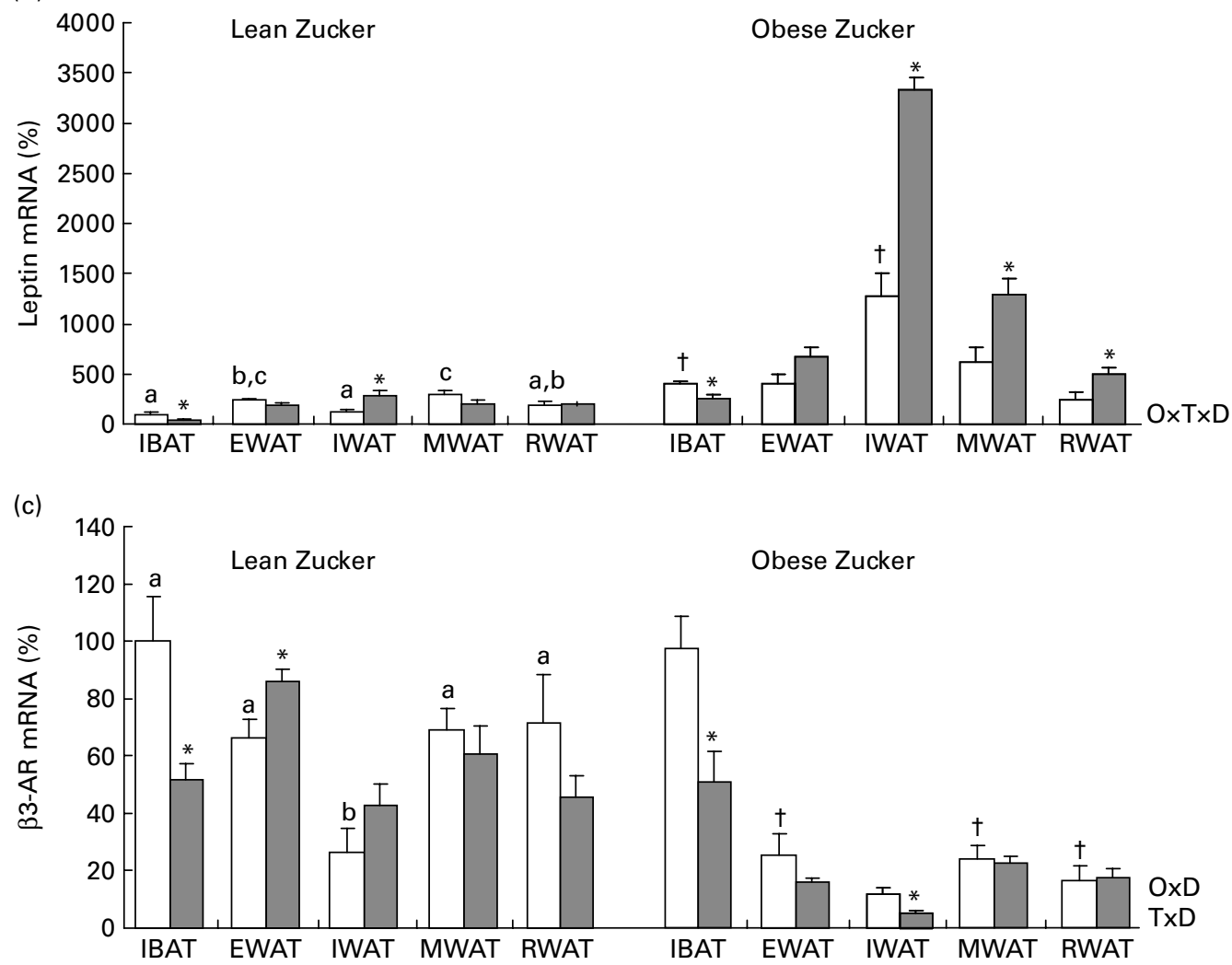

Fig. 1. Adiponutrin, leptin and 33 -adrenoceptor (AR) mRNA expression in the adipose tissue of ad libitum-fed control and cold-exposed lean and obese Zucker rats. (a) Adiponutrin, (b) leptin and (c) B3-AR mRNA expression levels were measured by real-time quantitative PCR analysis in interscapular brown adipose tissue (IBAT) and in different white adipose tissue depots: epididymal (EWAT), inguinal (IWAT), mesenteric (MWAT) and retroperitoneal (RWAT) in lean and obese Zucker rats acclimatised to $22^{\circ} \mathrm{C}$ (control, $\square$ ) and to $4^{\circ} \mathrm{C}$ for $24 \mathrm{~h}$ (cold, $\square$ ). Values are means $(n 5)$ of ratios of specific mRNA levels to lipoprotein receptor-related protein 10 , expressed as a percentage $v$. lean IBAT of the control group, which was set to $100 \%$, with standard errors represented by vertical bars. ${ }^{*}$ Mean values were significantly different for the effect of cold exposure $(P<0.05$, Student's $t$ test). † Mean values were significantly different for the effect of obesity (comparison between lean and obese animals of the control group: $P<0.05$, Student's $t$ test). ${ }^{a, b, c}$ Mean values with unlike letters were significantly different within lean animals of the control group $(P<0.05$, one-way ANOVA). $\mathrm{O} \times \mathrm{T}$, interaction of body weight and temperature; $\mathrm{O} \times \mathrm{D}$, interaction of body weight and adipose tissue depot; $\mathrm{T} \times \mathrm{D}$, interaction of temperature and adipose tissue depot $(P<0.05$, two-way ANOVA); $\mathrm{O} \times \mathrm{T} \times \mathrm{D}$, interaction of body weight, temperature and adipose tissue $\operatorname{depot}(P<0.05$, three-way ANOVA).

animals, $\beta 3$-AR mRNA levels were lower in the white adipose tissue depots than in brown adipose tissue (one-way ANOVA, $P<0.05)$. In response to cold, $\beta 3$-AR mRNA levels decreased in the brown adipose tissue of both lean and obese Zucker rats (Student's $t$ test, $P<0 \cdot 05$ ).
Effect of cold exposure on mRNA levels of genes involved in lipogenesis in brown and white adipose tissues

Cold exposure decreased mRNA levels of three important enzymes involved in lipogenesis: fatty acid synthase (FAS), acetyl-CoA carboxylase-1 (ACC1) and stearoyl-CoA 
desaturase-1 (SCD1) studied in the interscapular brown adipose tissue and in the epididymal white adipose tissue as selected depots. The effect was dependent on body weight (two-way ANOVA, $P<0.05$ ), as it was only observed in lean Zucker rats but not in the obese ones (Fig. 2), the same trend being observed for adiponutrin expression.

\section{Correlations of adiponutrin with lipogenic enzymes and uncoupling protein-1 gene expression}

When considering control and cold-exposed animals (both lean and obese), adiponutrin mRNA expression correlated positively with the expression of the lipogenic enzymes FAS, ACC1 and SCD1 in the two adipose depots studied (interscapular brown adipose tissue and epididymal white adipose tissue): $r 0.419, P=0.066$ for FAS, $r 0.475, P=0.034$ for ACC1 and $r 0.899, P<0.01$ for SCD1 in the brown adipose tissue; $r 0.872, P<0.01$ for FAS, $r 0.745, P<0.01$ for ACC1 and $r 0.883, P<0.01$ for SCD1 in the epididymal white adipose tissue. However, the correlation was more evident when considering only lean animals: $r$ 0.837, $P<0.01$ for FAS, $r 0.760$, $P=0.011$ for ACC1 and $r 0.971, P<0.01$ for SCD1 in the brown adipose tissue; $r 0.878, P<0.01$ for FAS, $r 0.755$, $P=0.012$ for ACC1 and $r 0.926, P<0.01$ for SCD1 in the
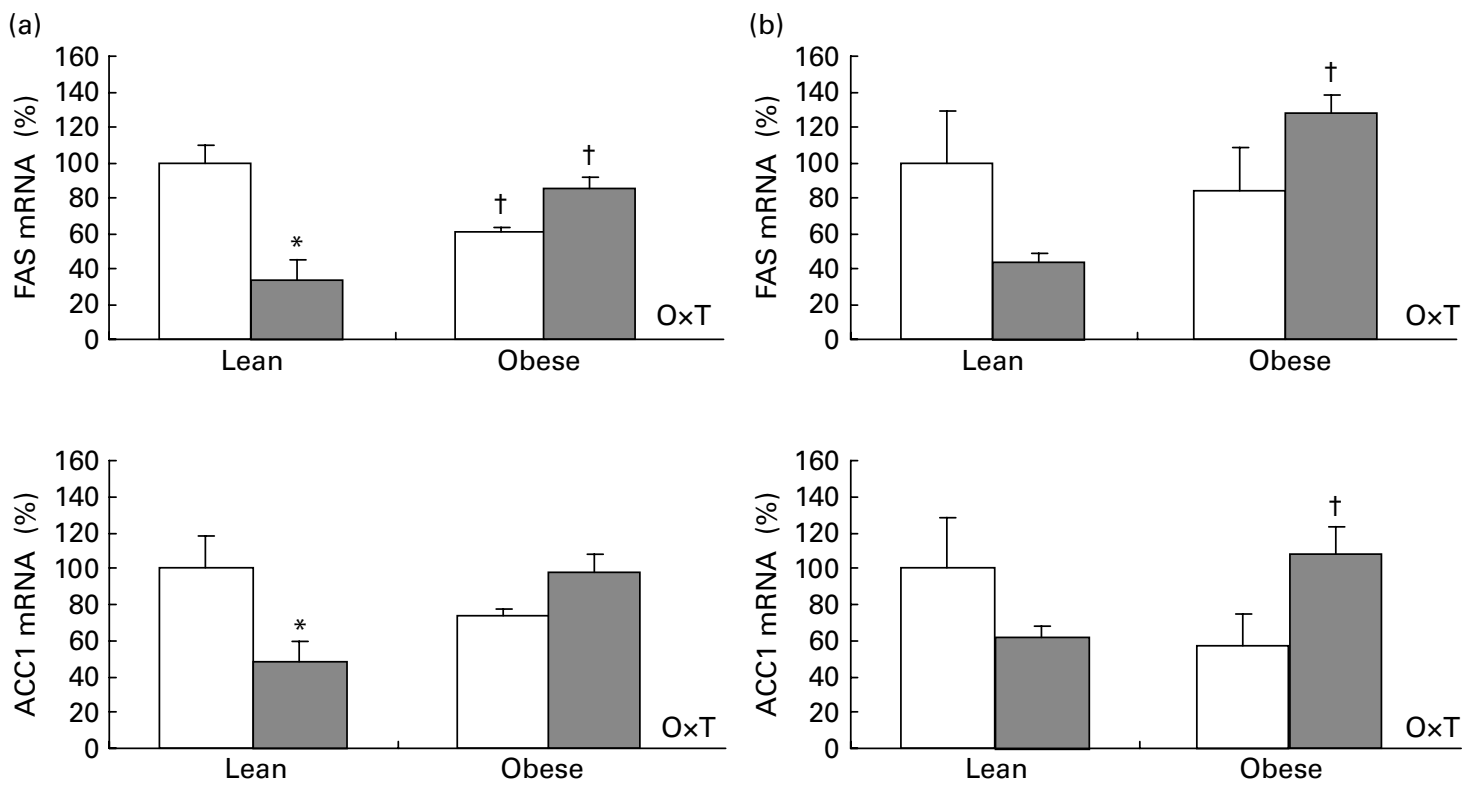

\section{Effect of isoprenaline treatment on adiponutrin mRNA levels in selected adipose tissue depots}

We were interested in testing whether the inhibition observed for adiponutrin mRNA expression in the adipose tissue after acute cold exposure was also observed with pharmacological adrenergic intervention in vivo. Acute intraperitoneal treatment with the non-selective $\beta$-agonist isoprenaline also produced an important decrease in adiponutrin mRNA expression in the mesenteric $(17 \cdot 8$ (SEM $7 \cdot 3$ ) \% in isoprenaline-treated $v .100$ ( $\operatorname{sem} 34) \%$ in control animals, Student's $t$ test, $P<0.05)$ and retroperitoneal (24.4 (SEM 6.6) \% in isoprenaline-treated $v .100 \pm 2 \%$ in control animals, Student's $t$ test, $P<0 \cdot 01)$ white adipose tissues. Mesenteric and retroperitoneal

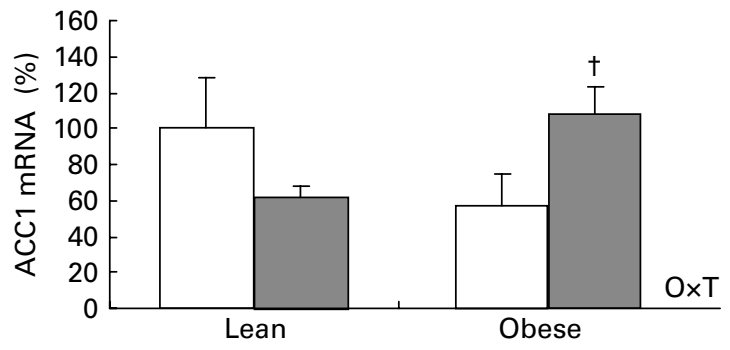

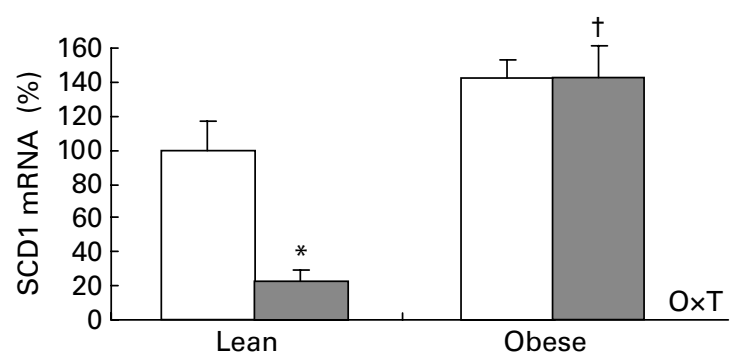

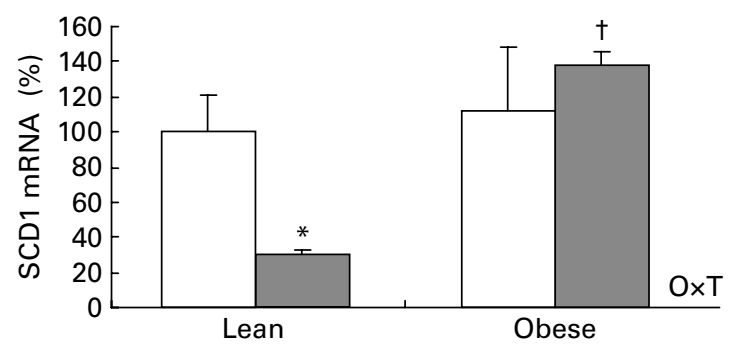

Fig. 2. Fatty acid synthase (FAS), acetyl-CoA-1 carboxylase (ACC1) and steraroyl-CoA desaturase-1 (SCD1) mRNA expression in the adipose tissue of ad libitum-fed control ( $\square$ ) and cold ( $\square$ )-exposed lean and obese Zucker rats. FAS, ACC1 and SCD1 were evaluated in the (a) interscapular brown adipose tissue and in the (b) epididymal white adipose tissue in the same conditions described in Fig. 1. 
adipose tissues were selected as representative depots because they were the ones with the greatest response to cold exposure. The decrease in adiponutrin expression observed in both depots ( $82 \%$ for the mesenteric and $76 \%$ for the retroperitoneal) was similar to that observed with cold exposure in the same depots. Isoprenaline treatment did not affect body weight, food intake or adiposity in the studied animals (data not shown).

\section{Effect of feeding conditions on adiponutrin mRNA levels in cold-exposed animals}

It is well known that in lean animals acclimatised to a standard housing temperature, adiponutrin is highly regulated by feeding conditions, decreasing by fasting and being completely recovered by refeeding ${ }^{(1,6-8)}$. But in lean animals exposed to cold (Fig. 3), fasting down-regulation of adiponutrin expression was lost in all the adipose depots studied. However, in these animals, refeeding for $3 \mathrm{~h}$ was a strong stimulus that was able to highly increase adiponutrin mRNA in brown adipose tissue and in mesenteric and retroperitoneal white depots (one-way ANOVA, $P<0.05$ ). In spite of this increased expression with refeeding, fed adiponutrin mRNA levels present in these tissues before cold exposure were not completely recovered.

In contrast to lean animals, in obese Zucker rats exposed to cold, adiponutrin mRNA expression responded to fasting (one-way ANOVA, $P<0.05$ ). There was an average decrease of $68 \%$ in adiponutrin mRNA levels in the different depots studied (Fig. 3). We have previously demonstrated in animals housed at $22^{\circ} \mathrm{C}$ that feeding regulation of adiponutrin expression is impaired in the obese state: the decrease with fasting is not as marked as in lean animals, and levels do not recover with refeeding ${ }^{(20)}$. However, the decrease in adiponutrin mRNA levels observed here in cold-exposed obese animals (68\%) was greater than that reported previously in obese Zucker rats acclimatised in normal housing temperature ( $49 \%$ decrease), indicating an improved nutritional regulation. As described at $22^{\circ} \mathrm{C}^{(20)}$, the response to refeeding was also impaired in cold-exposed obese animals, as there was not a complete recovery of the levels found previous to fasting (Fig. 3).

\section{Effect of noradrenaline treatment on adiponutrin and $\beta 3$-adrenergic receptor mRNA levels in white and brown adipocytes in culture}

To test whether the effects of cold exposure could be reproduced by the natural catecholamine noradrenaline, we treated brown adipocytes differentiated in culture from pre-adipocytes and white adipocytes differentiated from MEF with different concentrations of the hormone. As shown in Fig. 4(a), in both white and brown adipocytes, adiponutrin mRNA levels were down-regulated in a dose-dependent manner (one-way ANOVA, $P<0.05$ ). It is of note that the dose of noradrenaline necessary to decrease adiponutrin expression was higher for white than for brown adipocytes; a different density in specific AR could explain this fact.

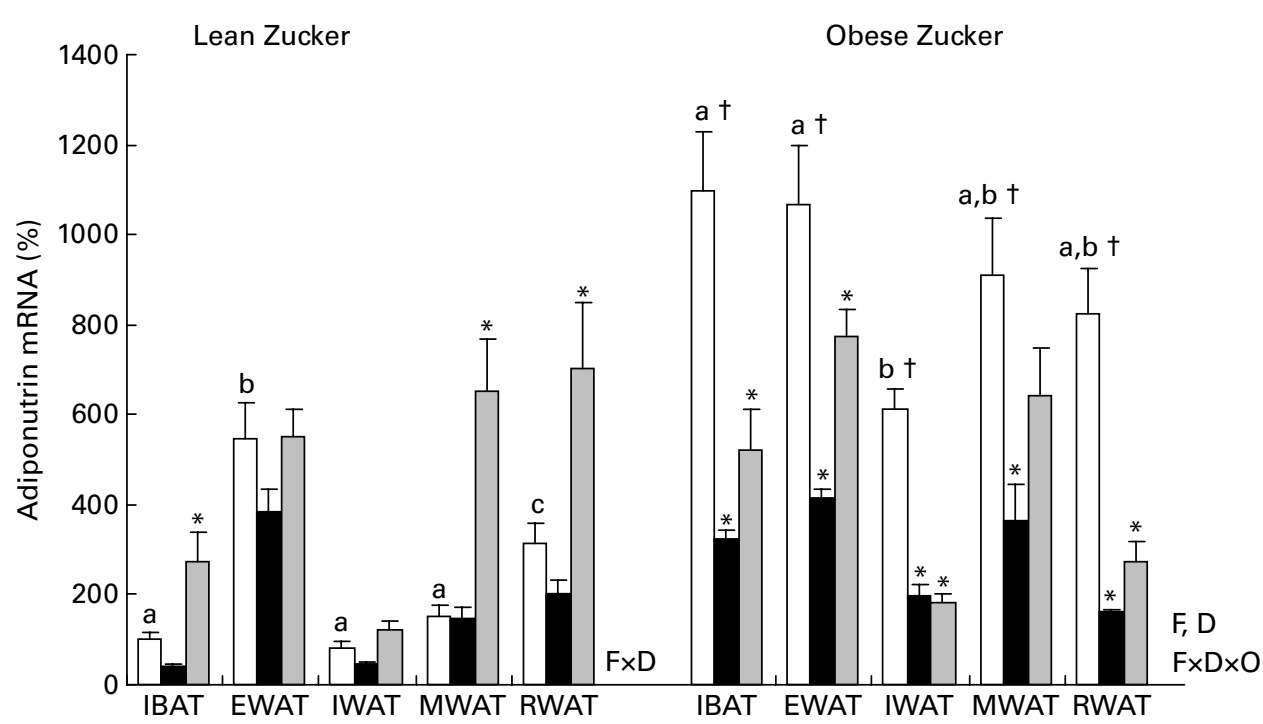

Fig. 3. Adiponutrin mRNA expression in the adipose tissue of cold-exposed lean and obese Zucker rats subjected to different feeding conditions. Adiponutrin mRNA expression levels in the interscapular brown adipose tissue (IBAT) and in the different white adipose tissue depots: epididymal (EWAT), inguinal (IWAT), mesenteric (MWAT) and retroperitoneal (RWAT) in lean and obese Zucker rats acclimatised to $4^{\circ} \mathrm{C}$ for $24 \mathrm{~h}$ and subjected to different feeding conditions were measured by real-time quantitative PCR analysis. Fed $(\square)$ animals had ad libitum access to food, fasted ( $\square$ ) animals were deprived of food for $14 \mathrm{~h}$ and re-fed ( $\square$ ) animals were given free access to food for $3 \mathrm{~h}$ after $14 \mathrm{~h}$ of fasting. Values are means $(n 5)$ of ratios of specific mRNA levels to lipoprotein receptor-related protein 10 , expressed as a percentage $v$. lean IBAT of the fed group, which was set to $100 \%$, with standard errors represented by vertical bars. ${ }^{\star}$ Mean values were significantly different for the effect of feeding conditions ( $v$. feed animals): $(P<0.05$; Student's $t$ test). $†$ Mean values were significantly different for the effect of obesity: $\left(P<0.05\right.$; Student's $t$ test). ${ }^{a, b, c}$ Mean values with unlike letters were significantly different within the different adipose depots of fed lean and obese animals, respectively $(P<0.05$; one-way ANOVA). $\mathrm{F}$, effect of feeding conditions; $\mathrm{D}$, effect of the adipose tissue depot; $\mathrm{F} \times \mathrm{D}$, interaction of feeding conditions and adipose tissue depot $(P<0.05$; two-way ANOVA); $\mathrm{F} \times \mathrm{D} \times \mathrm{O}$, interaction of feeding conditions, adipose tissue depot and body weight $(P<0.05$; three-way ANOVA). 
(a)
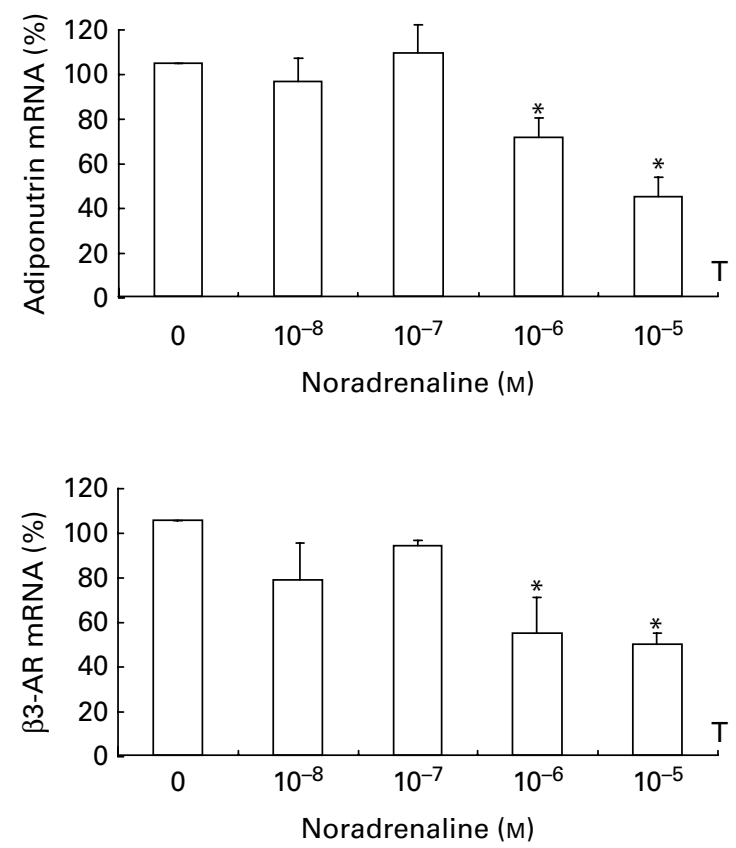

(b)
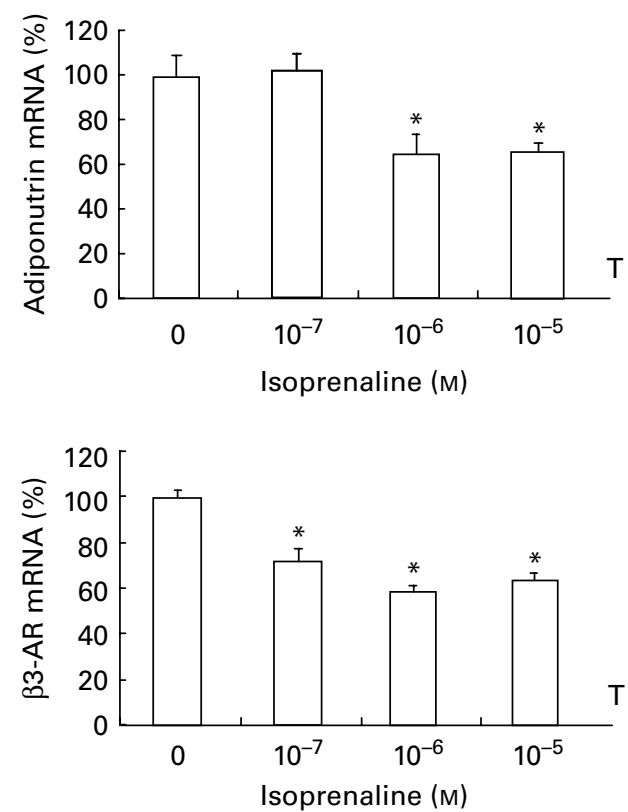

Brown adipocytes
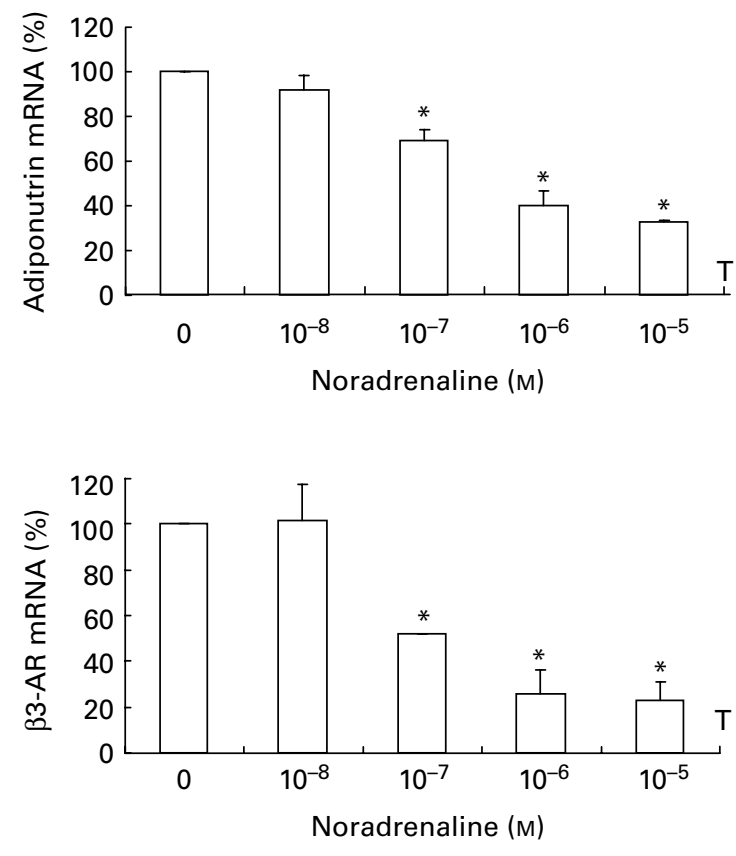

(c)

White adipocytes
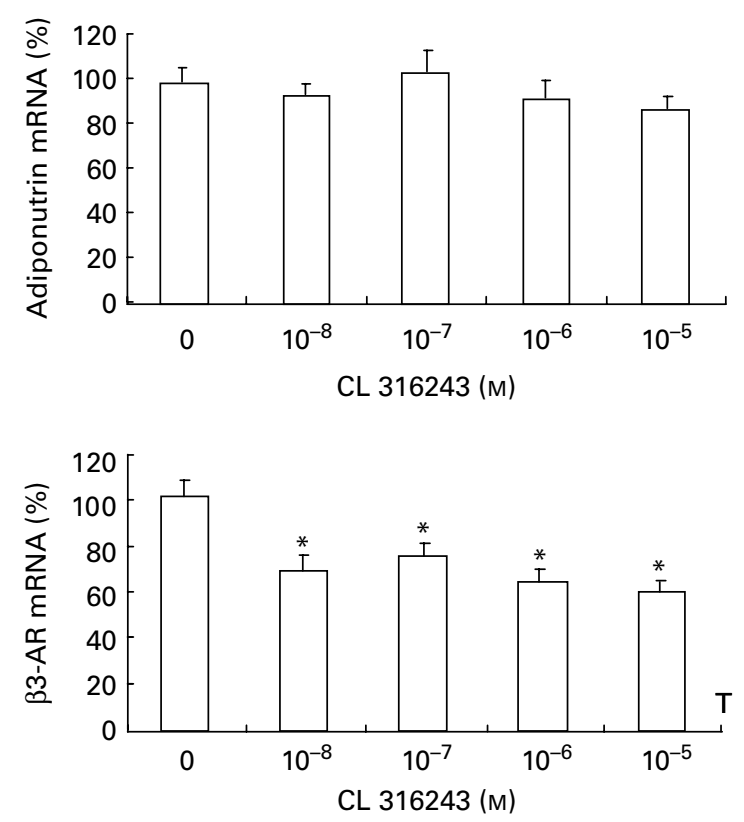

Fig. 4. Adiponutrin and $\beta 3$-adrenoceptor (AR) mRNA expression in cultured adipocytes treated with noradrenaline, isoprenaline and $C L 316243$. Adiponutrin and B3-AR mRNA expression levels in brown adipocytes differentiated in culture from pre-adipocytes and in white adipocytes differentiated from mouse embryonic fibroblasts treated with different concentrations of (a) noradrenaline, and in white adipocytes treated with (b) isoprenaline and with (c) CL 316243 . Treatment with the different compounds lasted for $24 \mathrm{~h}$. mRNA levels were measured by real-time quantitative PCR analysis. Data correspond to ratios of specific mRNA levels to lipoprotein receptor-related protein 10 in the noradrenaline and CL 316243 treatment and to guanosine diphospate dissociation inhibitor 1 in the isoprenaline treatment, expressed as a percentage of the value obtained for untreated cells. Values are means of two (for brown adipocytes) and three (for white adipocytes) independent experiments performed in duplicate, with standard errors represented by vertical bars. ${ }^{*}$ Mean values were significantly different from those of non-treated control $(P<0.05$; Student's $t$ test). T, effect of noradrenaline treatment $(P<0.05$; one-way ANOVA). 
In agreement with previous reports ${ }^{(30,35,36)}$, we found a down-regulation of $\beta 3$-receptor gene expression in cultured adipocytes in response to noradrenaline stimulation. $\beta 3$-AR is the main adrenergic receptor mediating the effects of noradrenaline and of a cold stimulus on adipose tissue ${ }^{(37-39)}$ and, as such, down-regulation of its mRNA levels has been viewed as a retro-regulatory response to sympathetic stimulation $^{(30)}$.

To determine whether the inhibitory effect of cold/ noradrenaline treatment was $\beta 3$-mediated, we also treated cultured white adipocytes with different doses of the selective $\beta 3$ agonist CL 316243. As was observed with noradrenaline, the treatment with CL 316243 decreased $\beta 3$-AR levels; however, no change was observed in adiponutrin mRNA levels (Fig. 4(c)). Thus, in order to establish the implication of $\beta$-receptors in adiponutrin expression, we treated white adipocytes with the agonist isoprenaline acting on the three $\beta$-AR ( $\beta 1, \beta 2$ and $\beta 3$ ). The results show a decrease as a result of isoprenaline treatment in both adiponutrin and $\beta 3$-receptor mRNA expression (Fig. 4(b)). These results point out to a role of $\beta 1 / \beta 2-\mathrm{AR}$ mediating the inhibitory effect of cold/noradrenaline in adiponutrin expression.

\section{Discussion}

Exposure to cold induces a substantial increase in metabolic rate and overall energy expenditure, particularly in small mammals, and has a profound effect on adipose tissue and lipid metabolism. Cold stimulus increases sympathetic activity and catecholamines released from sympathetic innervations, acting mainly through $\beta 3$-adrenergic receptors, stimulates fat mobilisation (lipolysis) in white adipose tissue, and thermogenesis in brown adipose tissue by oxidation of fatty acids, and also regulates adipokine production, to ensure survival $^{(26,40,41)}$. Adiponutrin is a protein mainly expressed in adipose tissue whose function in lipid metabolism has not yet been established, although it has a potential lipolytic and lipogenic role ${ }^{(1)}$. The study of the effect of cold on adiponutrin expression could help in determining its physiological role.

The present results show that in lean Zucker rats, a situation of increased energy demand ( $24 \mathrm{~h}$ exposure to $4^{\circ} \mathrm{C}$ ) highly decreases adiponutrin mRNA levels in brown adipose tissue and in the different white adipose tissue depots studied (except in the subcutaneous one). This pattern supports a role of this protein in lipogenic rather than in lipolytic processes. In obese rats, however, the decrease in adiponutrin mRNA levels in response to the cold stimulus is impaired, as it occurs only in brown adipose tissue and in the retroperitoneal white depot, and to a lesser extent than the decrease observed in lean animals. Other responses to cold exposure, regulated by sympathetic innervation, have been shown to be impaired in obese Zucker rats ${ }^{(38,42)}$. In fact, we found that the expression of the $\beta 3$-adrenergic receptor (the major mediator of sympathetic activation) is lower in the different white adipose depots of obese animals. Thus, obesity is associated with a resistance to sympathetic action on adipose tissue ${ }^{(38)}$, and this factor may underlie the impaired response to the inhibitory effect of cold on adiponutrin expression observed in obese Zucker animals. Although the cause of the insensitivity to cold observed in obese animals is far from being fully understood, in the case of obese Zucker animals, it could also be the lack of a functional leptin receptor, as leptin increases sympathetic stimulation ${ }^{(38,43)}$. However, although it cannot be excluded that leptin receptor deficiency could contribute to the impairment of adiponutrin regulation by cold exposure in obese rats, it is not a determinant, as in these animals, adiponutrin is down-regulated in two of the studied depots: the brown adipose tissue and the retroperitoneal white adipose depot.

The effect of cold on adiponutrin expression could be mediated through sympathetic stimulation. In fact, the physiological effect of cold was mimicked in vivo by treatment with the non-specific $\beta$-agonist isoprenaline. In addition, our in vitro studies give further details on adiponutrin adrenergic regulation. Adiponutrin mRNA levels decreased in cultured adipocytes when treated with noradrenaline and with isoprenaline $(\beta 1 / \beta 2 / \beta 3$ agonist), but not with the selective $\beta 3$-agonist CL 316243. Thus, the down-regulation of adiponutrin mRNA expression in response to cold/ noradrenaline appears to be mediated, at least in part, via $\beta 1 / \beta 2-\mathrm{AR}$, and not via the more classic $\beta 3$, although an implication of $\alpha$-AR cannot be excluded. In any case, we cannot discard either other factors such as circulating NEFA and insulin. NEFA have been recently described as activators of adiponutrin expression: they promote its transcription and inhibit its degradation ${ }^{(14)}$. In this way, the observed decrease in circulating NEFA in cold-exposed animals could also be related to the decrease in adiponutrin expression. Insulin is also a known activator of adiponutrin expression $^{(4)}$. Thus, this hormone could also been implicated in adiponutrin response to cold, as it has been described a decrease in insulin levels as a result of cold exposure $^{(44)}$. Nevertheless, as we only detect a decrease in insulin levels in obese cold-exposed animals, in which adiponutrin down-regulation by cold is impaired, changes in insulin levels seem not to be especially relevant to explain the observed effects. In addition, it is of note that cold produced a reduction of food intake, in both lean and obese rats, which could also explain, in part, the decrease in adiponutrin expression observed in animals of the cold group.

Interestingly, a similar behaviour after $24 \mathrm{~h}$ of the cold stimulus was observed when analysing three key lipogenic enzymes. The expression of FAS, ACC1 and SCD1 decreases as a result of cold exposure and this effect is present only in lean animals, indicating also in this case insensitivity in response to cold in obese rats. In fact, there is a positive correlation between the expression of adiponutrin and these enzymes, which is particularly evident for lean animals, indicating similar regulatory mechanisms. Moreover, there is a negative correlation between adiponutrin mRNA levels and expression of UCP1, the marker of the thermogenic capacity in brown adipose tissue, which is related to lipolytic activity in this tissue. A similar regulatory profile for adiponutrin and lipogenic enzymes has also been evidenced in animals treated 
with lipoic $\operatorname{acid}^{(45)}$. In these animals, there was an important decrease in the serum and liver concentrations of TAG as well as in adiponutrin, FAS and SCD1 (among other lipogenic enzymes) mRNA levels in liver ${ }^{(45)}$.

Taken together, the present data suggest a role of adipocyte adiponutrin more involved in the storage of energy as fat than in its mobilisation. This role would be in agreement with the regulation of adiponutrin by feeding conditions (decrease with fasting/increase with refeeding $)^{(1,6-8)}$ and with recent studies indicating that adiponutrin increases its expression in response to the important lipogenic transcription factor sterol regulatory element binding protein $1 \mathrm{c}$ in cultured hepatocytes $^{(13,14)}$. Nevertheless, although it is mainly expressed in adipose tissue, adiponutrin seems to be relevant in hepatic steatosis. An adiponutrin polymorphism that abolishes the lipolytic capacity of the enzyme ${ }^{(18)}$ has been related to increased lipid accumulation in liver ${ }^{(16,17)}$. These results indicate that, in addition to a lipogenic role, adiponutrin could also be involved in lipolytic processes in liver. All in all, adiponutrin could have an important function in lipid homeostasis, thanks to a pivotal lipogenic/lipolytic capacity. With the present data available, we can hypothesise that as a result of an excess of energy, adiponutrin could contribute to its storage as fat in adipocytes and maybe in hepatocytes, and in liver, it could also contribute to fat hydrolysis. Adiponutrin would be preventing, in this way, the complications related to an excessive energy intake.

Although it cannot be considered as an adipokine because it is not secreted, adiponutrin has been related to the same regulatory pathways of several adipokines, mainly leptin, a hormone with an important role in energy homeostasis that produces satiety and stimulates energy expenditure ${ }^{(6)}$. With this background, we were interested in comparing the response of both proteins to the cold stimulus. It is well known that the sympathetic system is a key regulator of leptin production ${ }^{(38)}$. Coincident with what has been observed for adiponutrin, cold exposure has been shown to induce suppression of leptin gene expression in the adipose tissue of rodents ${ }^{(26)}$, and to decrease circulating levels of the hormone ${ }^{(26,46)}$. This effect for leptin is mediated by the activation of the sympathetic system through the $\beta 3$-AR subtype ${ }^{(24,47)}$. The similar effect of cold exposure on leptin and adiponutrin expression is other data supporting the similarity of both proteins in terms of sharing common regulatory mechanisms. When analysing the present results, we only observed a cold-responsive down-regulation in leptin expression in brown adipose tissue, maybe because of its higher sympathetic innervation, and both in lean and obese Zucker rats. Although in other species, such as mice, cold exposure produces a decrease in leptin expression in white and brown adipose tissues ${ }^{(26)}$, the lack of response to cold in white adipose depots of rats has previously been reported, and it is not dependent on the duration of the cold stimulus $^{(48)}$. Hence, although adiponutrin and leptin share common regulatory mechanisms, adiponutrin would be a more potent acute sensor, in rats, of stimuli affecting energy homeostasis, such as exposure to cold or, as described previously, acute changes in feeding conditions (fasting/refeeding) $)^{(1,6-8,20)}$. Surprisingly, in obese Zucker rats, leptin mRNA levels increased with cold in the white adipose depots studied. As far as we know, this is the first time this process has been described, and could be tentatively related to the important decrease observed with cold exposure in circulating insulin basal levels, which could lead to an enhancement of sensitivity to the stimulatory effects of insulin in leptin expression ${ }^{(49,50)}$.

Adiponutrin expression is tightly regulated by feeding under habitual room temperature conditions, decreasing with fasting and recovering by refeeding ${ }^{(1,6-8)}$, and this regulation is impaired in the obese state ${ }^{(20)}$. We were also interested in studying adiponutrin regulation by feeding conditions in a situation of cold exposure, both in lean and obese Zucker rats. Probably due to the decrease in adiponutrin mRNA levels as a result of the cold stimulus, adiponutrin down-regulation by fasting is not evident in any of the adipose depots studied in lean Zucker rats. However, refeeding for $3 \mathrm{~h}$ is a strong stimulus that is able to increase adiponutrin expression in brown adipose tissue and in the mesenteric and retroperitoneal white adipose tissue depots, counteracting the inhibitory effect of cold. Perhaps these two depots have a higher sensitivity to the adiponutrin stimulatory effect of insulin, whose levels increase with refeeding. Zucker obese rats generally adapt less effectively to diet-related stimuli than their lean counterparts ${ }^{(51)}$. We have previously described that feeding regulation of adiponutrin expression is impaired in the obese state ${ }^{(20)}$. Our data show that in a situation of cold exposure, there is an improvement in adiponutrin regulation by fasting in the obese rats. Cold exposure diminishes circulating insulin $^{(44)}$, so the improved sensitivity to fasting could be due to the decrease in basal insulin levels that we have observed in obese cold-exposed rats, in combination to the presence of a situation of increased sympathetic stimulation that has been demonstrated to down-regulate adiponutrin expression.

In conclusion, here we demonstrate that adiponutrin expression in adipose tissue is down-regulated in a situation of increased energy demand, as is $24 \mathrm{~h}$ of cold exposure, in a process that could be mediated by catecholamines via $\beta 1 / \beta 2$-AR (as suggested by in vitro experiments), following the same behaviour as key lipogenic enzymes, and that this down-regulation is impaired in a situation of obesity. Moreover, an improvement in metabolic parameters associated with obesity in cold-exposed animals is related to an improvement in adiponutrin regulatory capacity. These data suggest that a proper function of adiponutrin in adipose tissue could be necessary to maintain a proper body weight, probably due to its function promoting adipocyte energy storage or lipid remodelling in situations of energy excess. In addition, although the exact physiological role of this protein is not well established and independently of this, alterations in adiponutrin regulation in response to factors affecting lipid metabolism/energy homeostasis (cold exposure/feeding conditions) could be used as a marker to detect metabolic deregulations associated with obesity and to go further into the study of the molecular mechanisms operating in this pathology. 


\section{Acknowledgements}

CIBER de Fisiopatología de la Obesidad y Nutrición is an initiative of the Instituto de Salad Carlos III (ISCIII). This study was supported by the Spanish Government (Ministerio de Educación y Ciencia, AGL 2009-11277/ALI). Our laboratory is a member of the European Research Network of Excellence NuGO (The European Nutrigenomics Organization, EU Contract: FOOD-CT-2004-506360 NUGO). The authors declare no conflict of interest. The author's responsibilities were as follows: A. P., P. O. and A. C. developed the experimental design; A. C. performed the major part of the experimental work; R. D.-R. contributed to the in vitro studies; P. O. collaborated in the animal studies; P. O., A. C., R. D.-R. and A. P. analysed and discussed the results; P. O. wrote the manuscript and A. P., A. C. and R. D.-R. participated in the critical revising of the manuscript. All authors read and approved the final manuscript.

\section{References}

1. Baulande S, Lasnier F, Lucas M, et al. (2001) Adiponutrin, a transmembrane protein corresponding to a novel dietaryand obesity-linked mRNA specifically expressed in the adipose lineage. J Biol Chem 276, 33336-33344.

2. Jenkins CM, Mancuso DJ, Yan W, et al. (2004) Identification, cloning, expression, and purification of three novel human calcium-independent phospholipase A2 family members possessing triacylglycerol lipase and acylglycerol transacylase activities. J Biol Chem 279, 48968-48975.

3. Lake AC, Sun Y, Li JL, et al. (2005) Expression, regulation, and triglyceride hydrolase activity of adiponutrin family members. J Lipid Res 46, 2477-2487.

4. Kershaw EE, Hamm JK, Verhagen LA, et al. (2006) Adipose triglyceride lipase: function, regulation by insulin, and comparison with adiponutrin. Diabetes 55, 148-157.

5. Basantani MK, Sitnick MT, Cai L, et al. (2011) Pnpla3/ Adiponutrin deficiency in mice does not contribute to fatty liver disease or metabolic syndrome. J Lipid Res 52, 318-329.

6. Polson DA \& Thompson MP (2003) Adiponutrin mRNA expression in white adipose tissue is rapidly induced by meal-feeding a high-sucrose diet. Biochem Biophys Res Commun 301, 261-266.

7. Bertile F \& Raclot T (2004) Differences in mRNA expression of adipocyte-derived factors in response to fasting, refeeding and leptin. Biochim Biophys Acta 1683, 101-109.

8. Polson DA \& Thompson MP (2004) Macronutrient composition of the diet differentially affects leptin and adiponutrin mRNA expression in response to meal feeding. $J$ Nutr Biochem 15, 242-246.

9. Liu YM, Moldes M, Bastard JP, et al. (2004) Adiponutrin: a new gene regulated by energy balance in human adipose tissue. J Clin Endocrinol Metab 89, 2684-2689.

10. Johansson LE, Hoffstedt J, Parikh H, et al. (2006) Variation in the adiponutrin gene influences its expression and associates with obesity. Diabetes 55, 826-833.

11. Faraj M, Beauregard G, Loizon E, et al. (2006) Insulin regulation of gene expression and concentrations of white adipose tissue-derived proteins in vivo in healthy men: relation to adiponutrin. J Endocrinol 191, 427-435.

12. Moldes M, Beauregard G, Faraj M, et al. (2006) Adiponutrin gene is regulated by insulin and glucose in human adipose tissue. Eur J Endocrinol 155, 461-468.
13. Dubuquoy C, Robichon C, Lasnier F, et al. (2011) Distinct regulation of adiponutrin/PNPLA3 gene expression by the transcription factors ChREBP and SREBP1c in mouse and human hepatocytes. $J$ Hepatol 55, 145-153.

14. Huang Y, He S, Li JZ, et al. (2010) A feed-forward loop amplifies nutritional regulation of PNPLA3. Proc Natl Acad Sci U S A 107, 7892-7897.

15. Liang G, Yang J, Horton JD, et al. (2002) Diminished hepatic response to fasting/refeeding and liver $\mathrm{X}$ receptor agonists in mice with selective deficiency of sterol regulatory elementbinding protein-1c. J Biol Chem 277, 9520-9528.

16. Romeo S, Kozlitina J, Xing C, et al. (2008) Genetic variation in PNPLA3 confers susceptibility to nonalcoholic fatty liver disease. Nat Genet 40, 1461-1465.

17. Kotronen A, Johansson LE, Johansson LM, et al. (2009) A common variant in PNPLA3, which encodes adiponutrin, is associated with liver fat content in humans. Diabetologia 52, 1056-1060.

18. He S, McPhaul C, Li JZ, et al. (2010) A sequence variation (I148M) in PNPLA3 associated with nonalcoholic fatty liver disease disrupts triglyceride hydrolysis. J Biol Chem 285 , 6706-6715.

19. Chen W, Chang B, Li L, et al. (2010) Patatin-like phospholipase domain-containing 3/adiponutrin deficiency in mice is not associated with fatty liver disease. Hepatology $\mathbf{5 2}$, $1134-1142$.

20. Caimari A, Oliver P \& Palou A (2007) Regulation of adiponutrin expression by feeding conditions in rats is altered in the obese state. Obesity (Silver Spring) 15, 591-599.

21. Johansson LE, Lindblad U, Larsson CA, et al. (2008) Polymorphisms in the adiponutrin gene are associated with increased insulin secretion and obesity. Eur J Endocrinol 159, $577-583$.

22. Trayhurn P (2005) Endocrine and signalling role of adipose tissue: new perspectives on fat. Acta Physiol Scand 184, 285-293.

23. Puerta M, Abelenda M, Rocha M, et al. (2002) Effect of acute cold exposure on the expression of the adiponectin, resistin and leptin genes in rat white and brown adipose tissues. Horm Metab Res 34, 629-634.

24. Giacobino JP (1996) Role of the $\beta 3$-adrenoceptor in the control of leptin expression. Horm Metab Res 28, 633-637.

25. Polson D \& Thompson M (2003) Adiponutrin gene expression in 3T3-L1 adipocytes is downregulated by troglitazone. Horm Metab Res 35, 508-510.

26. Trayhurn P, Duncan JS \& Rayner DV (1995) Acute cold-induced suppression of ob (obese) gene expression in white adipose tissue of mice: mediation by the sympathetic system. Biochem J 311, 729-733.

27. Matthews DR, Hosker JP, Rudenski AS, et al. (1985) Homeostasis model assessment: insulin resistance and $\beta$-cell function from fasting plasma glucose and insulin concentrations in man. Diabetologia 28, 412-419.

28. Puigserver P, Herron D, Gianotti M, et al. (1992) Induction and degradation of the uncoupling protein thermogenin in brown adipocytes in vitro and in vivo. Evidence for a rapidly degradable pool. Biochem J 284, 393-398.

29. Hansen JB, Jorgensen C, Petersen RK, et al. (2004) Retinoblastoma protein functions as a molecular switch determining white versus brown adipocyte differentiation. Proc Natl Acad Sci U S A 101, 4112-4117.

30. Roca P, Rodriguez AM, Oliver P, et al. (1999) Brown adipose tissue response to cafeteria diet-feeding involves induction of the UCP2 gene and is impaired in female rats as compared to males. Pflugers Arch 438, 628-634. 
31. Livak KJ \& Schmittgen TD (2001) Analysis of relative gene expression data using real-time quantitative PCR and the 2(-Delta Delta C(T)) method. Methods 25, 402-408.

32. Gabrielsson BG, Olofsson LE, Sjogren A, et al. (2005) Evaluation of reference genes for studies of gene expression in human adipose tissue. Obes Res 13, 649-652.

33. Caimari A, Oliver P, Keijer J, et al. (2010) Peripheral blood mononuclear cells as a model to study the response of energy homeostasis-related genes to acute changes in feeding conditions. Omics 14, 129-141.

34. Oliver P, Pico C \& Palou A (2001) Ontogenesis of leptin expression in different adipose tissue depots in the rat. Pflugers Arch 442, 383-390.

35. Scarpace PJ, Matheny M \& Tumer N (1999) Differential down-regulation of beta3-adrenergic receptor mRNA and signal transduction by cold exposure in brown adipose tissue of young and senescent rats. Pflugers Arch 437, 479-483.

36. Bengtsson T, Cannon B \& Nedergaard J (2000) Differential adrenergic regulation of the gene expression of the $\beta$ adrenoceptor subtypes $\beta 1, \beta 2$ and $\beta 3$ in brown adipocytes. Biochem J 347, 643-651.

37. Lafontan M \& Berlan M (1993) Fat cell adrenergic receptors and the control of white and brown fat cell function. J Lipid Res 34, 1057-1091.

38. Rayner DV (2001) The sympathetic nervous system in white adipose tissue regulation. Proc Nutr Soc 60, 357-364.

39. Watanabe M, Yamamoto T, Mori C, et al. (2008) Coldinduced changes in gene expression in brown adipose tissue: implications for the activation of thermogenesis. Biol Pharm Bull 31, 775-784

40. Nicholls DG \& Locke RM (1984) Thermogenic mechanisms in brown fat. Physiol Rev 64, 1-64.

41. Cannon B \& Nedergaard J (1985) The biochemistry of an inefficient tissue: brown adipose tissue. Essays Biochem 20, $110-164$
42. Bing C, Pickavance L, Wang Q, et al. (1997) Role of hypothalamic neuropeptide $\mathrm{Y}$ neurons in the defective thermogenic response to acute cold exposure in fatty Zucker rats. Neuroscience 80, 277-284

43. Jequier E (2002) Leptin signaling, adiposity, and energy balance. Ann N Y Acad Sci 967, 379-388.

44. Torsoni MA, Carvalheira JB, Pereira-Da-Silva M, et al. (2003) Molecular and functional resistance to insulin in hypothalamus of rats exposed to cold. Am J Physiol Endocrinol Metab 285, E216-E223.

45. Huong DT \& Ide T (2008) Dietary lipoic acid-dependent changes in the activity and mRNA levels of hepatic lipogenic enzymes in rats. Br J Nutr 100, 79-87.

46. Hardie LJ, Rayner DV, Holmes S, et al. (1996) Circulating leptin levels are modulated by fasting, cold exposure and insulin administration in lean but not Zucker $(\mathrm{fa} / \mathrm{fa}$ ) rats as measured by ELISA. Biochem Biophys Res Commun 223, 660-665.

47. Trayhurn P, Duncan JS, Rayner DV, et al. (1996) Rapid inhibition of ob gene expression and circulating leptin levels in lean mice by the beta 3-adrenoceptor agonists BRL 35135A and ZD2079. Biochem Biophys Res Commun 228, 605-610.

48. Moinat M, Deng C, Muzzin P, et al. (1995) Modulation of obese gene expression in rat brown and white adipose tissues. FEBS Lett 373, 131-134.

49. Saladin R, De Vos P, Guerre-Millo M, et al. (1995) Transient increase in obese gene expression after food intake or insulin administration. Nature 377, 527-529.

50. Leroy P, Dessolin S, Villageois P, et al. (1996) Expression of ob gene in adipose cells. Regulation by insulin. I Biol Chem 271, 2365-2368.

51. Specter SE, Hamilton JS, Stern JS, et al. (1995) Chronic protein restriction does not alter energetic efficiency or brown adipose tissue thermogenic capacity in genetically obese (fa/fa) Zucker rats. J Nutr 125, 2183-2193. 